\title{
Research beyond the hospital walls
}

\section{Introduction}

Reading widely is not only good for children. Although 'publish or perish' has tended to replace 'read or be dull' in academic life, reading beyond the clinical literature gives us grown-ups a better understanding of children's lives and histories as well as our own. This article provides pointers to the kinds of work with something important to say about children's well-being beyond hospital or clinical settings. The more we understand - as medical education reminds us - that bodies are not just a bunch of organs, and that medicine is only one of many determinants of good child health, the more fun it can be to see what we might learn from people on whose shoulders we stand, whatever their discipline.

Earlier articles in this series discuss the imperative to build on what we know, and to ask the kinds of questions that children, parents and healthcare professionals would like to see answered. Whilst internet searches and systematic reviews have improved the working lives of many researchers and students working on child health, these tend to under-represent books, work in the grey literature and work from disciplines outside medicine. Although it is a truism that re-inventing the wheel is wasteful, there are temptations in medicine to favour a medicine-wheel, drawing only on the medical literature.

We declare a bias. Just as radiologists call for more radiology and pharmacologists for more and better drugs, we, as sociologists are rather partial to sociology. We include a number of subject areas here, so this is no sociological wheel, but the social sciences predominate.

\section{Background}

While many children and parents have good reason to be grateful to bench scientists and clinicians for advances in the diagnosis and treatment of sick children, much of the research that has improved children's life chances and health has been carried out by engineers, economists, transport and town planners, geographers, sociologists and anthropologists. The settings for this academic labour include street corners ${ }^{1}$, communities ${ }^{2}$, schools and families ${ }^{3}$, and even ships taking children from the UK to a 'fresh start' in another country ${ }^{4}$ - our very own unaccompanied child migrants. This work, as well as that of social scientists inside the clinic such as Strong's study of paediatric outpatient clinics ${ }^{5}$ and Bluebond-Langner's classic work on dying children ${ }^{6}$ bring to the table insights, findings, methods and analytical tools. Methods are important. They need to be well-aligned with the research question, as conceded by a clinician and former chair of the National Institute for Health and Care excellence (NICE) who described the benefits of diverse research methods - including qualitative work - beyond the RCT. ${ }^{7}$ The hierarchy of evidence has been discredited in favour of selecting the right kind of research design to answer the question asked. ${ }^{8}$ If we want to know what matters as 
well as what counts, what constitutes value for money for parents and children ${ }^{9}$ as well as for the treasury or the Confederation of British Industry (CBI), we need to cast our nets widely.

Over the last few decades, work on 'intervening' to produce better outcomes for children or the adults they will become has been characterised by a good deal of activity, of which only a relatively small proportion address the structural reforms required to reduce inequalities in child health. The first example below however addresses neither an intervention in the conventional sense, nor individual health, but serves as a timely historical warning for our uncertain times.

\section{History}

The scholarly science journalist Steve Silberman in his book Neurotribes ${ }^{10}$ and Danny Dorling's discussion of exclusion and inequalities provide an understanding of the ways in which dangerous ideologies may be justified as 'science.' Ideas around eugenics - 'improving' the population through selective breeding - caught the imagination of economists including political and social reformers from the late nineteenth century onwards, though as Dorling $(p, 112)$ points out, the genocide perpetrated in the second world war largely exorcised this way of thinking. ${ }^{11}$ That said, ideas of 'fitness' and its association with 'burden' and 'cost' have a pervasive influence, though one would hope that a letter to the Lancet in 1989 would not find airspace today. In this communication, a paediatrician describes a family where the parents were reluctant to have an intervention that might endanger their seriously disabled child's life. He writes: 'it is unlikely that active interference or treatment would make much difference to her well-being, but may there not be temptation for a child to be inappropriately kept going.. to maintain the family income ?' (The family were receiving allowances, well below the costs of institutional care. $)^{12}$

It had been 'scientific' justification rather than costs or political ideology which brought paediatricians to the table in the Third Reich in their first systematic attempt to eliminate a population group - children with disabilities ${ }^{13}$. Shevell ${ }^{14}$ warns: It is all too easy to ignore and forget - to believe that the abuses all happened a long time ago, in a place much different from our own, with actions committed by marginal, extremist physicians to people who are not like us (p452). The history of interventions in children's lives (from Herod and boy babies onwards) has been mixed. Many of the great humanitarian advances have come about through charitable enterprises and political movements. But the high moral ground can be elusive. Within the lifetimes of older readers, British charities were sending children overseas for a new start using much the same arguments as those marshalled by parents sending their children to the west as unaccompanied migrants. The philanthropist Thomas Barnardo (referred to as Dr Barnardo, but never a doctor) supported such measures, writing: 'If you send out lads and lasses of pluck and principle ... you'll hear stories of success that would put the plot of many a fashionable novel to blush' (p30). ${ }^{15}$ 


\section{'Education}

The UK has a strong history of practice and scholarship in early years' education. The first nursery school in England was started in 1914 in Deptford by early years' pioneers, Margaret and Rachel McMillan. ${ }^{16}$ Ahead of their time, this was an open-air nursery where the child comes under the influence of the great healers, earth, sun, air, sleep and joy.' It has long been known that a major determinant of health is education, and for many children, reading and writing are not only part of the pathway to a better life, but enjoyable in the here and now and at times a welcome escape to a different world. Promotion of early years' education and a good understanding of the difference this can make was revived by the Commission on the Social Determinants of Health and subsequent reports in relation to both global health, and health in England. ${ }^{17-19}$

Good education confers considerable health (and other) benefits, not only for children and adolescents but also for the adults they will become. ${ }^{20}$ This suggests that the demands that health researchers make on children's and teachers' time need to be very well-justified (as does the organisational disinclination to provide hospital appointments for children at times which do not disrupt their education).

\section{Geography}

Maps are beautiful things as Dorling and his colleagues make clear in their description of Worldmapper which presents data in a way that is accessible to school children and researchers alike, and can help interpret the world and our place in it, in relation to education, crime, poverty and much else. ${ }^{21}$

There is a strong association between housing and health and Smith and colleagues et al make the (evidence-informed) assertion that the test of a well-functioning housing system is the well-being of its occupants. ${ }^{22}$ In a qualitative study, Nettleton and Burrows spoke to children and parents whose homes had been repossessed, and found shame and uncertainty about the future among the long lasting after-effects. ${ }^{23}$ While it is hardly surprising that those who do not occupy a home at all have poor outcomes, as a communication by Shaw and Dorling on the mortality of young street sleepers made clear ${ }^{24}$, the scale of the difference between the street population and the general housed population was (and remains) shocking.

It should not require evidence that cold, damp housing is a risk to child health, but a benefit of tying evidence to health rather than social justice is that medicine has the edge in terms of influence. Platt and colleagues' cross-sectional study of a random sample of households with children, involving assessments of housing conditions and health found that the mean number of symptoms was higher in damp and mouldy houses and higher still where the dampness and mould were severe. ${ }^{25}$ These 
differences persisted after controlling for factors frequently used, then as now, to place any blame squarely on parents' smoking or lack of employment.

\section{Research design.}

Contrary to common assumptions, randomised controlled trials were first used in agriculture rather than medicine, and have increasingly been used in education and social care, where the question of whether something 'works' is as important as in medicine. It is increasingly clear that it is not enough just to test the relationship between an intervention and an outcome. To understand this relationship we need to know how it works and how children experience their health and health care, taking a 'horses for courses' approach to research design. In order to improve our understanding of how to create change, qualitative work, surveys and ethnographies have a lot going for them. Likewise, co-designed studies, described elsewhere in this series, where children, parents, clinicians and commissioners collaborate on research from its inception are likely to improve take up where this looks useful. A further research design where the UK has a particularly strong history is the birth cohort studies ${ }^{26}$ In these, a child is enrolled at birth and followed up at intervals through their life time, enabling researchers and policy makers to better understand who does best after a poor start in life, and what the protective factors may be. ${ }^{27}$ Cohort studies can provide an insight into changing social and family policies, and family types, as well as the factors in childhood which are associated with later health and social outcomes. It would be misleading to suggest that cohort studies provide complete answers to these questions, given that the context changes as the cohort ages, but they provide important pointers.

\section{Pathways to impact}

Historians, philosophers, social scientists and economists all shape the way in which children and young people are seen - or ignored. In his work in a paediatric out-patient clinic, the sociologist Phil Strong 5 noted that 'almost all children, even the older ones, were routinely and smoothly excluded from the bulk of consultations.' (p.9) Four decades on, it would be an unusual paediatrician who failed to include the child or young person, and an unusual medical sociologist who accepted the views Strong expressed at that time on children's competence. Similarly, the paediatric settings described by the anthropologist Myra Bluebond Langner in her work with dying children in 1980 are much changed, and our understandings of the ways in which children and mothers protect one another vividly highlighted by her story of a dying boy who would shout at his mother. He explained that he did this so she would miss him less when he died. When it came to the mother, she explained : "Myra, he knows when I can't take it in that room any more. ..he knows if he yells at me I'll leave. He also knows I'll come back." ${ }^{28}$ There is no simple causal pathway for our greater willingness to take children seriously, but social scientists have played a significant part. 
Alderson's work on children's rights ${ }^{29}$ and children's consent to surgery ${ }^{30}$, Mayall's work on children, health and the social order ${ }^{331}$, and Christensen's work on participation ${ }^{32}$, are among the studies overturning views of children as possessions or consumer durables, incompetent, or 'becoming' rather than being.

\section{Conclusions}

Most of the work described here gives us findings rather than 'results', context rather than forensic detail. Much of this kind of work does not attract eye watering research grants, but combined with research-informed advocacy (the geographer Danny Dorling's edited collection Fair Play is a good example) $)^{33}$, shows the ways in which research can be useful, used and make a difference to children's lives as well as our own. 'Finding out' as every child knows (and adults should), is fun. 


\section{References}

1. Foote Whyte W. Street corner society: The social structure of an Italian slum. Chicago and London: The University of Chicago Press 1981.

2. Roberts H, Smith SJ, Bryce C. Children at risk, safety as a social value. Buckingham: Open University Press 1995.

3. Mayall B. Children, health and the social order. Buckingham: Open University Press 1996.

4. Doyle A. Pauper children (Canada), Return to an Order of the Honourable: The House of Commons, 1875.

5. Strong P. The ceremonial order of the clinic. London: Routledge and Kegan Paul 1979.

6. Bluebond-Langner M. The private worlds of dying children. Princeton, New Jersey: Princeton University Press 1980.

7. Rawlins M. De testimonio: on the evidence for decisions about the use of therapeutic interventions. The Lancet 2008;372(9656):2152-61. doi: https://doi.org/10.1016/S01406736(08)61930-3.

8. Petticrew M, Roberts H. Evidence, hierarchies and typologies: horses for courses. Journal of Epidemiology and Community Health 2003;57:527-29.

9. Arai L, Panca M, Morris S, et al. Time, monetary and other costs of participation in family-based weight management interventions: qualitative and systematic evidence. PLoS One 2015;10(4):e0123782. doi: doi: 10.1371/journal.pone.0123782 [published Online First: Apr 8]

10. Silberman S. Neurotribes. London: Allen and Unwin 2015.

11. Dorling D. Injustice: why inequality persists. Bristol: Policy Press 2010.

12. Galloway CA. Disabled child as income. The Lancet 1989;April 22:907. doi: https://doi.org/10.1016/S0140-6736(89)92908-5

13. Parent $S$, Shevell M. The 'first to perish': child euthanasia in the Third Reich. Archives of Pediatric and Adolescent Medicine 1998;152(1):79-86.

14. Shevell M. Confronting the past: contemporary German paediatric response to medical practice in the Third Reich. Paediatrics \& Child Health 2000;5(8):451-2.

15. Barnardo T. Night and day: a monthly record of Christian missions and philantropy. London, 1884.

16. McMillan M. The nursery school. London: Dent and Sons 1919.

17. CSDH. Closing the gap in a generation. Geneva: World Health Organisation (WHO), Commission on the Social Determinants of Health, 2008.

18. Marmot M. Fair society, healthy lives. The Marmot review. Strategic review of health inequalities in England post-2010. London: The Marmot Review, 2010.

19. Dyson A, Herzman C, Roberts $\mathrm{H}$, et al. Childhood development, education and health inequalities. Taskforce report for Marmot, 2010.

20. Field F. The foundation years: preventing poor children becoming poor adults. Report of the independent review on poverty and life chances. In: Office TC, ed. London, 2010.

21. Dorling D, Barford A, Newman M. WORLDMAPPER: the world as you've never seen it. IEEE Transactions On Visualization And Computer Graphics 2006;12(5 September/October)

22. Smith $\mathrm{S}$, Cigdem M, Ong R, et al. Wellbeing at the edges of ownership. Environment and Planning A: Economy and Space 2017;49(5):1080-98. doi: https://doi.org/10.1177/0308518X16688471

23. Nettleton S, Burrows R. When a capital investment becomes an emotional loss: the health consequences of the experience of mortgage possession in England. Housing Studies 2000;15(3):463-78. doi: 10.1080/02673030050009285

24. Shaw M, Dorling D. Mortality among street youth in the UK. The Lancet 1998;743(August 29)

25. Platt SD, Martin CJ, Hunt SM, et al. Damp housing, mould growth, and symptomatic health state.

BMJ 1989;298:1673. 
26. Pearson H. The life project. Harmondsworth: Penguin 2017.

27. Pilling D. Escape from disadvantage. Brighton: Falmer Press 1990.

28. Bluebond-Lagner M. [January 4th 2019]. Available from:

http://listen.health.org.uk/stories/myra-bluebond-langner/ accessed January 4th 2019.

29. Alderson P. Children's rights: exploring beliefs, attitudes, principles and practice. London: Jessica Kingsley 2000.

30. Alderson P. Children's concent to surgery. Buckingham: Open University Press 1993.

31. Mayall B. Towards a sociology for childhood: thinking from children's lives. Maidenhead: Open University Press 2002.

32. Christensen P. Children's participation in ethnographic research: Issues of power and representation. Children \& Society 2004;18:165-76.

33. Dorling D. Fair play. Bristol: Policy Press 2012.

' http://www.mcmillannurseryschool.co.uk/?p=2078 